heads of state made historic commitments to end the disease. These governments, supported by international and national partners, continue to shape the strategic direction of the global effort to roll back malaria. Nor are countries simply responding to donor-driven agendas or "led by private interests", such as foundations, manufacturing companies, Western advocates and non-governmental organizations. Now, financial grant-making by donors, such as the Global Fund to Fight AIDS, Tuberculosis and Malaria, is driven by national needs. The countries in which malaria remains endemic are at the helm, and are accountable for their performance and results.

This role of endemic countries in the current fight against malaria is a missing chapter in Shah's work. In fact, like their Western counterparts, African political, cultural, religious and sports figures have become highly vocal on the issue, promoting wider use of insecticide-treated mosquito nets, indoor spraying and effective medicines.

The global malaria-control strategy being implemented calls for both a holistic approach and a lasting commitment to disease control. The Global Malaria Action Plan (GMAP), shouldered by the Roll Back Malaria Partnership - of which I am executive director - brings together hundreds of development organizations, businesses, non-governmental organizations and endemic countries. The GMAP departs from the fast-track, magicbullet solution proposed by past campaigns. Championed by the entire malaria community, the plan is locally appropriate, using strategies adapted to the specific ecology and epidemiology of a country or region.

Without this bold, long-term vision of malaria eradication, it would be easy to abandon systematic control measures as soon as people stop dying from the disease. Here, Shah is forthright about the consequences. Sporadic action or discontinued efforts will cause a resurgence of the parasite and loss of life. By contrast, setting a far-reaching goal focuses the malaria research community on protecting existing tools by tackling emerging drug and insecticide resistance, as well as on developing new ways of combating this global killer.

Shah's ultimate message is spot on: that the fight against malaria is complex. Ending it, as she says, is tough and unlikely to happen in our lifetimes. Key actors from different sectors at national, regional and global levels need to harmonize their efforts. Today's malaria movement has brought both an unparalleled diversity of experience, knowledge, skills and resources to its cause, and far more coordination through an inclusive global consultative process. Hopefully, The Fever will bring new partners to the table.

Awa-Marie Coll-Seck is executive director of the Roll Back Malaria Partnership and former Minister of Health of the Republic of Senegal. e-mail:collsecka@who.int

\title{
Making the mundane urbane
}

\author{
At Home: A Short History of Private Life \\ by Bill Bryson \\ Doubleday: 2010.544 pp. $€ 20$
}

Any scientist-turned-writer who tries to popularize their work soon realizes how hard it is to captivate a reader. Surveying an entire field makes the account too dull; just throwing in personal stories makes it too random. The beauty and excitement that drew scientists to their research disappears. They need help.

Which is why Bill Bryson was created. His latest work, At Home, is a slow walk through an ordinary family home, bringing in the history of hygiene, energy use, lighting technology and much else on the way. Bryson lures readers into a discussion of science not by presenting the facts directly, but by offering a compelling vision of the home as a nexus at which history and technology meets. The reader develops a thirst to understand that vision, and in the process absorbs the science that underpins it.

Consider Bryson's discussion of household condiments. He starts with a conceptual curio: the remarkably low levels of nutrients required by our bodies. A single ounce of vitamin B1, for example, is all that we need to sustain an 80-year lifespan. Rather than list various vitamins or minerals and

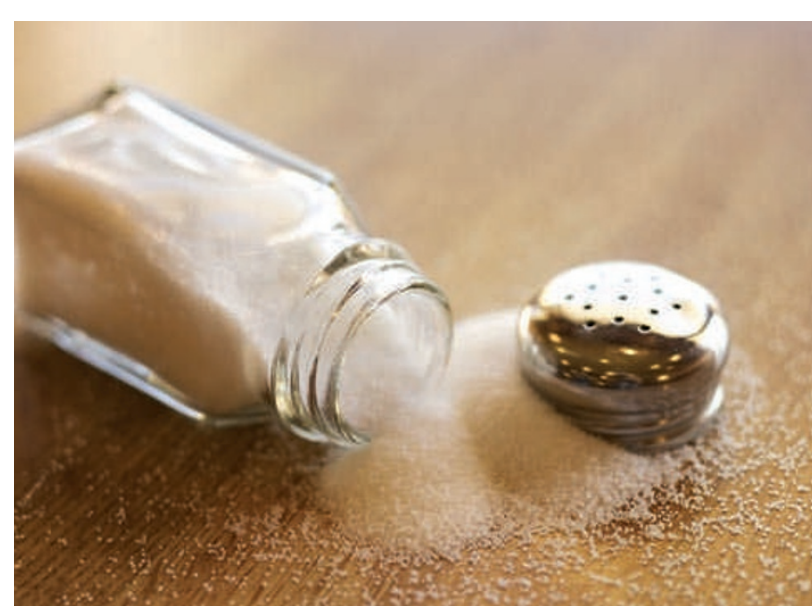

Before salt came in shakers, the Aztecs had to acquire it from urine. their requirements, Bryson describes human quirks that ordinary readers will recognize.

In discussing salt, for example, he points out that a lack of it makes you feel bad and eventually kills you, but "at no point would a human being think: 'Gosh, I could sure do with some salt'." Our interest whetted, Bryson inserts a deft explanation of its role: "without the chloride in salt, cells simply shut down, like an engine without fuel".

Along with his inspired associative thinking and 'science by stealth' approach, Bryson frames his stories with a light hand and considerable wit. Finding the required salt, he explains, called for some ingenuity by early humans: "Ancient Britons, for instance, heated sticks on a beach, then doused them in the sea and scraped the salt off. Aztecs, by contrast, acquired salt by evaporating their own urine. These are not intuitive acts, to put it mildly."

The humour and metaphors are needed because raw science rarely resonates with human feelings. The formation of atoms and the generation of elements, for example, are awe-inspiring - if one is thinking about time, creation and our place in the Universe. Otherwise, it is just the slotting together of particles by following certain rules: intriguing to scientists, but geeky to most people.

By the book's end, wider messages are apparent. One example is our immense luck in being alive now. Before flushing toilets, running water and supermarkets, people spent huge amounts of time lugging waste, water and food around. Millions of lives were squandered for generations, as many people performed these basic tasks for their more fortunate superiors.

Those superiors felt that their social position was not down to luck, but to birth and breeding. They berated their servants accordingly. Yet in colonial America, a labour shortage meant that servants were quick to escape this situation. Because they could easily leave their jobs to set up homes of their own, the servant class dwindled and a huge 
market arose for labour-saving machines. Even today we associate such devices - from the refrigerator to the rubbish compactor - with American values.

Ultimately, Bryson sees precariousness. Our comfortable homes exist today because we consume long-stored fuels, and lots of them.
Of all the energy produced since the Industrial Revolution began, "half has been consumed in the last twenty years" he notes.

Bryson finishes At Home by climbing to his attic and looking out on the world. Climate change is beyond the scope of this book, but he touches on the huge shifts that took place when electricity took over from coal and wood for domestic energy. His home is safe, inland in tranquil Norfolk. But how long will that security endure, if the sea level rises and our resources run out?

David Bodanis is author of $E=m c^{2}$. His next book is on the history of the Ten Commandments.

\section{Pioneers of plant genetics to flower on stage}

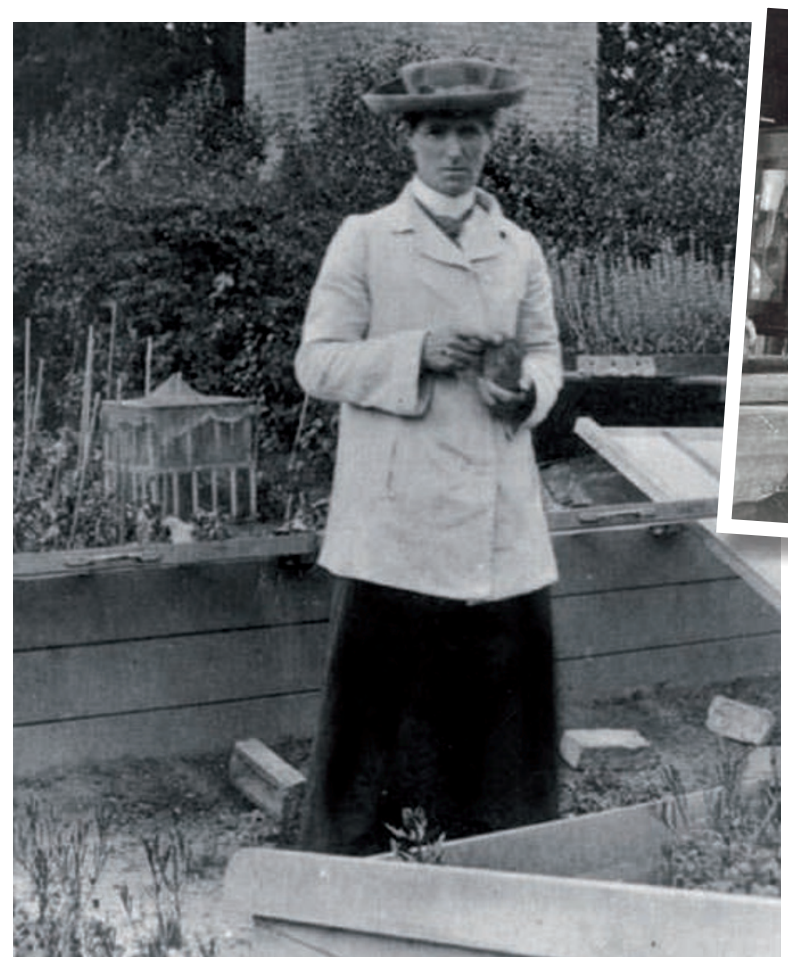

Blooming Snapdragons

by Liz Rothschild. Directed by Sue Mayo 14 July, Royal Institution, London

In the late nineteenth century, a group of female scientists helped to lay the foundations of modern genetics through experiments in plant breeding. Their forgotten story is told in the play Blooming Snapdragons, written by Liz Rothschild and directed by Sue Mayo, which will receive its first London performance at the Royal Institution next week.

Dee Rawsthorne, outreach coordinator at the John Innes Centre in Norwich, UK, commissioned the play to restore the women to their rightful place in the historical record. At a time when higher learning in the sciences was largely closed to females in Britain, the women worked at the University of Cambridge alongside William Bateson, who coined the word

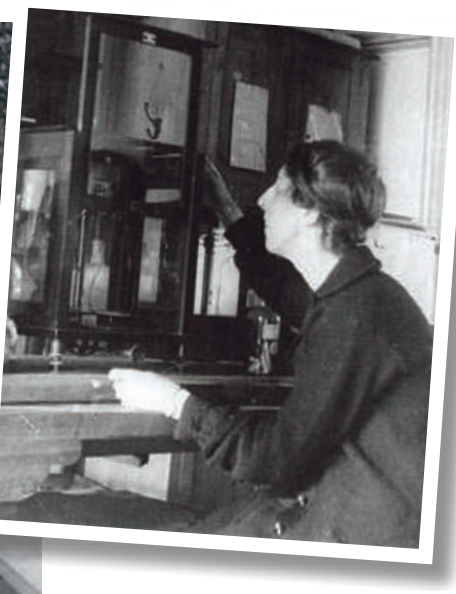

Rebecca Saunders (left) and Muriel Wheldale made vital contributions to early plant genetics.

genetics. He later became the first director of the John Innes Centre's forerunner, the John Innes Horticultural Institution, which was founded in London in 1910.

At Cambridge, Bateson led a programme of mainly plant-based research, where his promotion of the rediscovered Mendelian theory of inheritance made him an outsider. His wife Beatrice was his most devoted assistant, but he also found an able cohort of colleagues among the women who were teaching and studying at the university's Balfour Laboratory, founded for members of the women's colleges in 1884 .

"The Balfour Laboratory was an essential place for women at the end of the nineteenth century," explains Rothschild. "It offered lab space to women students who were banned from other university laboratories and provided a tiny career ladder for female researchers."

The Balfour women included Rebecca Saunders, who in 1920 became the first female president of one of the sections of the British Association for the Advancement of Science; and Muriel Wheldale, who solved the complex inheritance of flower colour in antirrhinums - the 'blooming snapdragons' of the play's title. "These women are sunk in obscurity, and yet they were involved in an area of research that is extremely relevant today," says Rothschild.

In the show, Rothschild and Syreeta Kumar play two modern biologists, Jo and Adi, whose stories are interleaved with those of the historical characters. The dramatic structure turns on the parallels between Bateson's interest in inherited disorders and Adi's experience of genetic disease within her own family. Rothschild, who previously wrote and performed a play about US environmentalist Rachel Carson, drew on research into Bateson's lab by historian Marsha Richmond at Wayne State University in Detroit, Michigan.

I was fascinated to learn of Rothschild's work, having written my own one-woman play for the centenary of the birth of the Nobel prizewinner Dorothy Hodgkin. Hidden Glory was performed on 10 May by Miranda Cook and directed by Abbey Wright at the Oxford University Museum of Natural History, where Hodgkin ran her X-ray lab for more than 20 years.

With access to a huge archive of Hodgkin's letters and other writings, I fashioned a script that used her own words as far as possible, focusing on the work she did on penicillin during the Second World War while her children were very young. Rothschild faced a different challenge: giving voices to women who had left behind much less written material.

Given the powerful emotional engagement that takes place between actor and audience, I believe that theatre should be more extensively exploited in conveying the history of science. Rothschild agrees, adding that, "It has been fascinating to explore the beauty and bravery of the work, and I hope it will kindle in those watching a curiosity in and respect for the challenges facing science now." Georgina Ferry is a writer based in Oxford, UK, and author of the biographies Dorothy Hodgkin: A Life and Max Perutz and the Secret of Life.

See go.nature.com/wQLZHz for more information. 